\title{
Chapter Six: \\ The Danish Press during the German Occupation: Between Indirect and Direct Control and from Dominant to Negotiated Reading
}

\section{Palle Roslyng-Jensen}

Compared with all other occupied countries in Europe during the Second World War the conditions for the Danish daily press, including the dissemination of news and the public debate through the press, was in a category of its own. German control of the press and German direction of the press were carried out with "a velvet glove on the iron fist". That is, seen in a European perspective, with considerable moderation, except for the last period of the occupation, although practically no Dane was in doubt of where ultimate control was vested.

The goal of this chapter is to discuss what the control and censorship system meant for the degree of adaptation of the press to the authorities exercising the control of the press, and what it meant for the reception of newspapers and the interpretation of news and comments in a democratic context. Radio broadcasting and clandestine press will be considered as they are functioning as competitors and alternatives to the daily "legal" press. The term "democratic" means in this respect the existence of a pluralistic newspaper (and other media) system and the possibility for the editors and journalists to use generally accepted media and journalistic standards of the time and for the public a free choice between different media. The empiric foundation of the chapter is to a significant degree dependant on my own research on attitudes and opinions in Denmark during the Occupation based on personal diaries, where opinions are placed in connection with media messages and media habits during the occupation (Roslyng-Jensen 2007).

The questions asked in the chapter are:

1) To what degree did Danish newspapers meet the goals and expectations of the occupation authorities to support the established occupation system in Denmark and to participate in establishing a friendly attitude to the Germans and a positive attitude to the German war effort?

2) To which degree did the control of Danish authorities, the professional standards and regulations of the press itself function in accordance with democratic ideals, even though, the press system, as such, was under heavy non-democratic influence and control?

3) How were the readers of the newspapers influenced by the media messages?

It is the general conclusion of this chapter, that, by controlling the press, the Germans safeguarded some support for the occupation system until August 1943, while their goals of establishing a friendly attitude among the Danish public to the Germans, their 
political system and their war effort were never met, not even to the lowest level of German expectations.

The control system of the press was, during most of the occupation period, in some respects a common interest for the German occupation authorities and for the Danish Government and administration. As long as the German authorities worked within this understanding it safeguarded these interests. In the last one and a half years of the occupation the Germans, in some areas, worked against the interests of the Danish administration, and were therefore weakening their original goals in upholding a system of occupation with indirect German rule. In this period the German indirect occupation rule was, to a large degree, continued by the functioning of a Danish administration working with the unofficial authority and support of the leaders of the main political parties.

On the question of creating pro-German Danes the intervention and efforts of the control system to influence the Danes worked counter-productively. The harder the German efforts and the more extensive the German interventions in the press, the more the attitudes of the Danish population developed in opposition to the political and ideological values of the German system. In these areas the German authorities were functioning as the worst enemy of their own goals. This was not due to the Danish authorities or the press itself, but due to the occupation situation as such, the general attitudes of the Danes to the Germans and Nazism, and the existence of alternative media. To some degree the press, despite censorship, compulsory news and comments, succeeded in keeping manifest German or Nazi propaganda at some distance, or making it obvious for the readers, when such articles and news were printed. For creating this general awareness of the readers the alternative media generally had a considerable significance.

From April 9, 1940 to August 29, 1943 the control system of the press was indirect, while a direct German censorship was introduced after August 29, 1943. In several areas the guidance and control of the Danish authorities and the formally self-imposed regulations of the press were harder to ascertain and evaluate for the public than a direct censorship, seen from the standards of an open and pluralistic formation of opinions. Expectations and rumors of censorship and control meant that readers and the audience met the press and especially news and comments on news with scepticism, also in cases where the control was not active, and the existence of alternative media like British and Swedish broadcasting meant a higher consciousness of foreign control and the existence of attempts to influence the individual reader or listener. Expectations of censorship and control often had more effect than control and censorship itself, and as such served as an effective counter control.

On the question of general support or opposition to the cooperative or adaptive policy of the Danish Government and Danish institutions, the press functioned like other main institutions and generally supported the cooperative policy until the summer of 1943, and their messages and opinions were received much like the messages of political parties, Government ministers and other Danish officials. 
In Norway and in most other occupied countries in Western Europe the German occupation system was marked by a more direct rule than in Denmark, and in the case of Norway a much more conscious attempt to create support for and suppress criticism of the local Nazi-orientated party, Nasjonal Samling (NS), and the German occupation rule. The result was a more divided journalistic community than in Denmark. For most Danish editors and journalists some amount of adaptation was necessary to keep their jobs and the majority worked in the controlled press from the beginning of occupation till the end, while Norwegian journalists often only had the choice between participating in direct NS-orientated propaganda or to leave their job or even go into exile. The question of working under indirect control and self-censorship was therefore especially pronounced in Denmark.

\section{The media system during occupation}

A general description of the Danish media system during the German Occupation is a necessary background for answering the questions asked. For the majority of the population the media system comprised four different media categories:

1) Daily printed newspapers: Under some German control and surveillance until August 29, 1943, but mainly through an indirect system organized and directed by the Press Bureau of the Danish Foreign Ministry and with a tribunal judging violations organized and manned by the press itself. After August 29, 1943 direct censorship was introduced.

2) Radio news from Statsradiofonien (Danish State Broadcasting), called Pressens Radioavis (Radio Newspaper of the Press): Directed by representatives of the printed press, politicians and representatives of the State Broadcasting. Danish Broadcasting was from the beginning of the Occupation under more direct German control than the printed press. All sources agree that there was a clear decline in the amount of listeners to radio from Danish State Broadcasting, especially to radio news, and many listened to it together with news from the BBC or Sweden and made comparisons (Boisen 1965, Christiansen et. al. 1950, 163).

3) The Counter-media: Radio news from Britain in the Danish language and from Sweden in Swedish had an extensive audience in Denmark right from the beginning of the occupation. The majority of Danes listened regularly to the BBC in Danish, a sizable minority to news from Sweden, and the most addicted news listeners tuned in to both stations. It should be mentioned that the BBC and Swedish Radio were under British and Swedish Government control, and for the first couple of years, their control was in several respects almost as extensive as the German control of the press and radio in occupied Denmark, although with more open standards and with less use of misleading news.

The clandestine press had some coverage from the end of 1942 and the beginning of 1943, and a more extensive circulation after August 1943. Compared with Nor- 
way and the Netherlands, where radios were confiscated, the dissemination of news had less importance in Danish clandestine papers. Instead, propaganda against the adaptive policy of the Government was important until August 29, 1943, after that date the ideological and political differences between different papers were clearly expressed in the papers, and even the main political parties were behind some clandestine papers. At this stage a pluralistic public debate was more often found in clandestine papers than in the controlled press, which grew more and more uniform and uninteresting (Bennett 1966, Stenton 2000; Lauridsen 1997, 261-385).

4) Direct personal communication in closed and open meetings, rumours and discussions among people: Personal communication had a larger significance than in ordinary times and it influenced the reception of news in the media in several respects.

Each of the media categories must be seen in connection with the other categories, as they were competing for the attention and trust of the Danes. If the direct influence by the occupation power was increased in one category, then the other media categories were influenced and received more readers or listeners.

\section{The historiography of the Danish press during the Occupation}

The historiography of the Danish press during the Occupation follows the main lines of the historiography on the official cooperative, adaptive or collaborationist policy.

Historical research on occupied Europe has stressed a tendency to exaggerate the influence and size of resistance movements and support for resistance. In the first years after the war practically everybody had resisted, if not in deeds then in their hearts. Collaboration was consciously or unconsciously forgotten or hidden. This tendency is called resistencialism (Rousso 1987, 19).

The earliest writing on the press in occupied Denmark is unquestionably resistencialist: Danes were united in their fight against the occupying power, and Danish traitors and collaborators were few and a distinct group. Politicians and the major institutions were also on the side of the resistance, when it was possible, if not actively, then through passive resistance, and the rest of the population gave the Germans and their collaborators "the cold shoulder". The press was, of course, a significant part of this general policy, and a number of anniversary publications of individual papers and autobiographies of leading editors and journalists advocate this position.

Later and with lesser vehemence the successful survival of institutions and values, that is democratic and national values, were stressed. This included the survival of democratic institutions, of a Danish administration and the non-Nazification of the institutions, the population and, of course, the press. The press may have given in on minor issues, but in general German demands were fought, Nazification avoided and the public informed with rather open standards as far as it was possible. The Press Bureau of the Foreign Ministry clearly supported this policy, and was generally on the side of the press. This is the main conclusions of the principal historical investigation 
of the press during occupation by L. Bindsløv Frederiksen, which was published in 1960 and financed by the organizations of the Danish press. The author was trained as a historian, but was working in an influential position in Danish State Broadcasting and therefore part of the media establishment of the time. The same conclusions are clearly visible in an early anniversary publication on Danish State Broadcasting written by influential employees and board members of the State Broadcasting (Christiansen et al. 1950, 163-293).

A later more critical research was stressing adaptation to the point of collaboration. Only one major publication is included in this category: Rasmus Kreth's study of Berlingske Tidende 1933-45, published in 1998. It was financed by the Berlingske publishing house marking the $250^{\text {th }}$ anniversary of its main paper and published by the paper, a quite extraordinary example of support for critical research in the past of the institution under investigation. The fairly recent general Danish media history has addressed the subject of the press during the Occupation, but is mainly covering development in press structure and how the pressure of control was met (Bruhn Jensen 2001).

\section{The national frame and negotiable interpretations}

In media theory it has been suggested, that media news and opinions are seen in interpretative packages within a more or less fixed frame, defined as "a central organizing idea for making sense of events". The two main frames of the occupation period were the national frame and the democratic frame (Liebes and Rieback 1994, 108-124).

The national frame was organized and structured from the fall of 1940 through mass meetings, national events like the King's birthday, communal singing (alsang to use a Swedish-inspired term) and a large amount of articles and broadcasts on Danish history, language and traditions, where mostly a national frame was used and to a lesser degree, the democratic frame. The limits of the control system were attacks on the Occupation authorities, on Germany and German policies and general attacks on the existence of a Danish Government and the April 9 agreement. A rather clear line was drawn during the end of 1940 between Danes inside a community of attitudes where, for instance, different conceptions of democracy and different conceptions on the interpretation of government policies was accepted, and Danes placed outside the community, which were Danes seen as working directly for the Germans, the German new order or Nazism. "A good Danish man or woman" was a loose but strongly dividing term, and it meant being against Danish Nazis, keeping the Germans at some distance and expressing and sharing patriotic sentiments, while working in a factory with German war contracts or producing agricultural products which were sold to Germany and support for the Danish Government was clearly acceptable for the majority population and within the lines for being "a good Dane". Reading the daily press reinforced these two frames into a rather fixed structure, which did not change much during the first almost 3 years of occupation. 
From media theory is taken the concepts of a dominant, a negotiated and an oppositional reading of news and opinions in the media. In the first case the message is accepted by the reader in accordance with the intent of the sender. In the second case it is consciously or unconsciously compared with other media messages, and the media message is approached with some distrust. The amount of confidence or distrust in the media in general, the writer, the message, the situation and the interpretation of the intent of the writer are all factors in the negotiated interpretation of the receiver. The last case is when the message is interpreted as the opposite of the intent of the sender: for instance if the German news mentions "a heroic German resistance at the Eastern Front" it is interpreted as a turbulent German flight. The occupation system and the control or censorship system meant that dominant reading of the press declined, negotiated reading was extended and in the last period of the war cases of oppositional reading are discernible.

\section{The press structure and the control system of the press 1940-45}

The daily newspaper system in Denmark in the first half of the $20^{\text {th }}$ century is named the "four-paper" system. A large number of provincial towns each had 3 to 4 different daily newspapers, each one of them associated with one of the four main political parties: The Conservatives, the Liberals, the Social Liberals and the Social Democrats. A local paper covered the town and the surrounding area. The papers were small in circulation and in size (that is number of pages), and the content was mainly: Telegrams from Ritzau (the leading Danish Press Agency), comments and articles from the Press Bureau of the party to which it adhered and local news and ads. The editor was a prominent member of the local party organisation, often member of the local community council, while staff consisted of just a couple of journalists or young people in training to become journalist. The paper was mostly owned by a group of notables connected with the party, or was part of a group of papers owned by leading supporters of the party, or in the social democratic case, trade unions. Local or national notables made up the board of the paper. Generally it was extremely difficult for such a paper to transgress the expectations of local readers and party leaders. Board members and readers expected news and comments within the narrow local and political framework, and to a large degree they got it.

A number of newspapers were regional and these had more resources than the majority of papers. Copenhagen newspapers were both regional with local news on Copenhagen, and national papers. Politically, therefore, the Copenhagen newspapers had a more extensive coverage of national politics, more coverage of cultural affairs and international news than the rest, and they often formed a rather closed circuit, discussing or attacking each other, and attracting commentaries, interviews and articles from the leading politicians. As there was no significant Copenhagen paper connected to the liberal party, a number of liberal regional papers were followed more intensely by the political establishment than other regional papers. The regional daily Jylland- 
sposten (independent bourgeois) had a larger circulation, more resources and bigger influence than the other regional papers. The more specialized papers comprised Kristeligt Dagblad, Børsen, the communist daily Arbejderbladet" and the Danish Nazi paper Fadrelandet (Fatherland). The Danish yellow press comprised mainly of a few papers printed by the largest newspaper conglomerates in Copenhagen. However for nearly all papers regardless of size or political affiliation, party politics on the national level and local politics came first. ${ }^{1}$

A very high percentage of Danish families subscribed to a newspaper. It was the outward sign of being a member of the local and national community, for the man of the house of being the breadwinner of the family and, very often, a member of a party, and for the working class male to be class conscious and politically conscious. Up to $80 \%$ of all families bought at least one paper, and 20-30\% more than one paper, often a local and a regional or a specialized paper. The papers were written for men, and first and foremost read by men. Reading one or two newspapers was not enough for most; in 1940 approximately $80 \%$ of all Danish families had a radio, and a very large percentage of the population listened to it every day, $80-90 \%$ of the radios were tuned in to the radio news at 12 a.m. or 7 p.m. (Christiansen et al. 1950, 131-162).

Seen from the preconditions of the time Danish men were quite well informed on local and national politics, but less so on international news. They felt secure within their own social and political group, and their opinions and attitudes were confirmed by reading a newspaper and listening to the news. Danish women were catching up, but still a significant step behind their men in attention paid to and time spent on news and politics, although the introduction of female suffrage took place 25 years earlier. Generally, there was a high acceptance of one's chosen media and its content, as the paper in its content and opinions was connected to one's own lifestyle and social and political position. These well established media habits and the reception of the media were changed during the occupation.

Immediately after April 9, 1940 a control system of the press was introduced, with the argument that the Allies in their warfare should not be able to benefit from the information they could obtain from news in the Danish media. It had to be based on arguments connected to the German defence of Denmark, as the Germans had promised not to interfere in the internal affairs of Denmark. Radio broadcasting and radio news were placed under direct German control, with controllers placed at the Danish Broadcasting Headquarters. Radio news was placed under direct censorship, while other kinds of radio programs were under more indirect control. The newspapers were only placed under indirect control. The system was arranged between The Danish Foreign Ministry and the press, with the Press Bureau of the Foreign Ministry acting as supervisor and controller. The Press Bureau issued rules for publication, both on the general level, and on a weekly basis, and papers were requested to submit questions on interpretation of the rules to the Press Bureau. A juridical system for judging violations of

1 Danish press structure and development in this period is described in Thomsen 1972; Thomsen and Søllinge 1991. 
the rules was established by representatives of the press organized in a tribunal consisting of leading editors from all four main political press groups, who fined violations, and by severe violations could order a stop to the publication of a paper for one or several days.

The whole system could be described as a self-imposed regulation of the press, to ensure that the press acted in accordance with the general policy of Danish institutions and the April 9 agreement. Like most other arrangements during the period of adaptation or collaboration, it was, of course, only accepted by the Germans as long as it served their interests in the long run. A German Press Attaché at the German Legation, that is the office of the German Plenipotary in Denmark, had the ultimate control. It was used with some moderation until August 1943, partly not to create too much political or popular opposition against the April 9 arrangement, which German authorities at this point saw as being advantageous for their rule in Denmark. At a later stage, this policy was maintained so as not to push the Danes towards listening to and trusting alternative media. Quite often the German authorities sought direct influence on the press, participating in meetings with the leading editors and the Press Bureau, and threatening direct censorship unless there was a more positive attitude towards Germany and German policies in the press. A number of journalists and editors were banned from the press, and in a number of cases, a ban on publication of a certain paper for a number of days, decided outside the juridical system of the press by a direct German order, was demanded.

After the resignation of the Danish Government on August 29, 1943 direct German censorship of the press was established. It was in the afternoon of August 29, 1943, that German Plenipotary Werner Best, after the introduction of martial law, at a meeting for the leading newspaper editors expressed: "That in this ridiculously small country the press has instigated the population with the attitude that Germany was weak, and that Germany would accept everything. From now on directions to the press would be orders." (Bindsløv Frederiksen 1960, 381). Newspapers in Copenhagen would require advance approval for articles, headlines etc. by German Authorities. Newspapers outside Copenhagen received extensive instructions on a daily basis. Gradually the Foreign Ministry Press Bureau succeeded in getting some modifications of the advance censorship, but was also met with German demands for more telegrams and articles written by German propagandists, in some cases without mention of the author or the source. Again here the Press Bureau achieved some concessions, which lead to some identification of source becoming accepted, for instance, when the source was declared as: "We have received from Ritzau's Bureau" or just "We have received". Practically every newspaper reader knew that it was an article emanating from the Germans. Generally Danes became very apt in reading between the lines or discerning half-hidden specifications of source. During the final 20 months of the occupation most newspapers were deeply influenced by censorship and other regulations. Newspapers had fewer pages because of paper rationing. Yet more types of articles and information were banned, and it was demanded that directly misleading telegrams be enclosed in the paper. 
Even so, compared with the rest of occupied Europe and with Germany, the Danish press also at this stage had a comparatively lenient censorship. It was possible for the readers to follow the main lines in the development of the war, if they knew that certain kinds of information were not included, and that words like withdrawal or defeat were only used in connection with the adversary. Often war news came from Danish newspaper correspondents in Berlin, where news was passed from the Press Bureau of the German Foreign Ministry. Although all news telegrams from the correspondents had to be approved by the Press Bureau in Berlin and by the German censorship authority in Copenhagen, the accuracy of war news from the Danish correspondents in Berlin was generally higher than readers could receive in most other occupied countries. ${ }^{2}$

The occupation and the cooperation among the main political parties and the national frame of the papers meant that nearly all newspapers were depoliticized compared with the situation before the occupation. There was some political debate on traditional political issues, but the question with highest priority: Responsibility for the occupation and surrender on April 9 and defense policy in the 1930s were only discussed with moderation and with the general understanding that a more thorough political reckoning would follow after the war.

\section{German goals and adaptation of the press}

In many respects the daily press was in the same position as many other Danish institutions, which the Occupation authorities were following closely. This meant a general pressure and admonishments from the Government to control the institutions and its employees in order to avoid direct German intervention. The German Plenipotary needed to be able to report to Berlin that he was in complete control and that German interests were fulfilled. In March 1941 during a very calm period in Danish-German relations, before sabotage had begun and with no clandestine papers published, Plenipotary Cecil von Renthe-Fink reported to Berlin on the control of Danish Press (Beretning til Folketinget ... XIII, bd.4, 248):

The Danish Press, which before April 9 strongly mirrored the Danish People's prevailing proEnglishness, has since the Occupation received a completely new face. It was obvious that, with regard to the German troops' presence we neither could allow an anti-German line in the Danish press nor that an atmosphere was created, directly or indirectly, that served our war enemies. Within these limits, the newspapers have consciously been given latitude, although kept under constant observation and influence. In this connection, we do not exercise censorship directly, but turn responsibility over to the competent Danish Government bureau, admittedly scrupulously supervised by us. In this way we have cut off our enemies' propaganda material and in addition avoided the public sabotaging of the press as "German propaganda". A positive achievement is that to an increasing degree, the newspapers on their own initiative and responsibility are begin-

2 Longerich 1987, 281-283; Hvidtfeldt (who served as correspondent in Berlin for Socialdemokraten) $1996,106-108$. 
ning to take a position to the German-Danish and European problems in accordance with our viewpoint.

The structure of the indirect control of the German supervision of the Press is accurately described in Renthe-Finks report. What is not mentioned, is that calm and order and acceptance of the occupation was the first goal of the German control of the press, a so-called positive achievement of the Danish press. That is to say, a positive attitude to Nazism and the German new order, came only second in priorities for the German press policy. On the question of support for the occupation arrangement the Danish press followed the directions of the Press Bureau rather accurately and willingly, although they sometimes found the directions too meticulous, but generally they did not go further than demanded, except in few and often well-known cases. Renthe-Finks report exaggerates the amount of direct ideological and political collaboration of the press. Generally the press did not participate in direct or indirect Nazification of the population, except of course papers from the Danish Nazi Party, quite the contrary to for instance Norwegian papers, where it was extremely difficult for journalists to avoid participating in pro-German or NS-ordered campaigns to influence the population.

Support for resistance, open anti-government policy and even clear support for the Allies was quite another matter, which was never instigated in the press. The expectations and values of the readers, fear of losing readers and survival of the paper were the ultimate considerations for most editors. In a personal and unpublished diary the chief editor of Ekstrabladet summed up his experience November 27, 1941: "In the last couple of days I have once again saved the paper from the intervention of the Press Bureau regarding a couple of telegrams, which the editorial secretariat did not stop ... How many times do the staff not reproach me for my care and caution, but God knows in the end whether or not they will give me full recognition, when the war is over? I expect it and hope it." 3 Actually, they did not give him recognition when the war was over. Then, courage was recognized, not caution. On the other hand he did not get in trouble either, and he shared the cautious editing of the paper not to have trouble with the Press Bureau or the Press Tribunal with the vast majority of editors.

The general policy of all Danish newspapers seen over the whole period was therefore one of adaptation. Historian Rasmus Kreth has concluded: "In general the press adapted to the circumstances ... and no paper or publication company placed itself in a position with absolute standards of freedom." (Kreth 1998, 9). If they had done so, it would of course have meant a stop to publication sooner or later. For the press, like all other institutions during the occupation, the golden rule of the cooperative policy was followed: To avoid what was considered the greater evil by giving in to what was considered the lesser evil. In this case the greater evil would have been a cessation of circulation, or on the political level, to let the Germans or the Danish Nazis have control of newspapers. The problem for the cooperative policy in general and for the press, was that the borderline between what was greater and lesser evils was pushed slightly 
all the time, although never into direct and consciously false or misleading news or comments written by the journalists or editors of the papers themselves.

It is not surprising therefore that the press in general accepted and defended the adaptive policy of the Danish Government and Danish authorities, not because they were obliged to do so, but out of consideration for continued circulation of their paper and because of shared beliefs. Fundamentally, the leading politicians, editors and the majority of journalists and the vast majority of the population, until the summer of 1943, shared these values to a high degree, and saw a Danish Nazi Government as the alternative to a Government headed by the main political parties, and therefore accepted adaptation to German demands. The newspapers and the editors, who were closely connected to the main political parties, generally defended Government policy to the last and warned against so-called private foreign policy.

This did not mean that all papers reacted uniformly towards the adaptive policy. There are examples from the first couple of months of the occupation, where articles were out of touch with the expectation and attitudes of their readers, such as Aalborg Stiftstidende in the afternoon edition on April 9, 1940 with a report on the occupation of Aalborg Airport almost expressing admiration for the German airmen, who took control of the airport the same morning, and a Viborg paper with a propagandistic picture of Hitler and a presentation of Hitler's birthday parade April 20, 1940 on the front page. Both gave rise to local criticism. Another example is the well known Politiken editorial April 28, 1940 on the publication of the official German explanation of the occupation of Denmark and Norway published April 27.4 The editorial expressed some agreement with the German explanation that the British had instigated the German occupation by violating the neutrality of the Scandinavian countries (which they actually did), with the wording, that under certain circumstances Churchill could be seen as a dangerous man. ${ }^{5}$ The reaction was a boycott campaign against the paper, and newspapers in Germany eagerly citing the editorial. The editorial was in fact inspired by Scavenius as chairman of the board for Politiken before he became Foreign Minister in July 1940. After the summer of 1940 and the so called "national revival" it is difficult to find such examples. All papers were now framed nationally on a general level, including Social Democratic and Social Liberal papers, and all papers agreed on attacking the Danish Nazi Party as far as it could be accepted by the Press Bureau and by the Press Tribunal. Open attacks on the Danish Nazi Party were later restricted after German demands, but the difference to conditions in Norway is obvious, where in Norway any kind of open attack on Nasjonal Samling in the controlled press was impossible.

While open criticism of German policy was rare in the Danish press, and would have been met with heavy sanctions, more or less hidden ridicule did occur. An indirect criticism of the occupation regime could, in some cases, be voiced by cautious attacks on individual politicians or separate government decisions, but only very cautiously

4 Beretning til Folketinget ... IV B, 14-18.

5 Examples from: Palle Roslyng-Jensen 2007; Bindsløv Frederiksen 1960, 44. 
in the editorials. More often a limited dissociation from the occupation power was voiced by stressing that Danes, the Danish social and political system and Danish traditions included national and democratic values and respect for individual liberties and everybody knew, without it being said, that this was contrary to German values. But supporting patriotic and democratic values also meant support for the King's and the Government's request for calm and order and support for authorities, and therefore some support for the April 9 agreement. This consequence was in accordance with German goals, and therefore support for national and democratic values was generally not met with opposition by the occupation authorities, if written within an accepted standard. This implied understanding of common interests between German authorities and the Danish Government was never voiced publicly except in the clandestine press, but it was accepted by both parties. The press was an important participant in this implicit and very general support for the occupation system lasting until August 29, 1943.

Some papers were known to enclose more hidden criticism of the occupation authorities than others: Kristeligt Dagblad and Nationaltidende were the most outspoken, and editors Gunnar Helweg-Larsen and Aage Schoch were forced out of their positions. A German demand for the dismissal of H.P. Sørensen, chief editor of the leading Social Democratic newspaper, Socialdemokraten, had as background his refusal to print a laudatory report from a German-arranged tour in Germany written by Harald Bergstedt, well-known author and social democratic journalist, who was in the process of turning closer to National Socialism. In spite of such examples the papers were generally all quite adaptive, even though nearly all major newspapers had examples of journalists who were dismissed after German demands, often after criticism of a single article or after personal attacks in the Danish Nazi newspapers. Fines by the Press Tribunal or a short temporary halt of publication could sometimes function as a national insurance in relationship to the subscribers of the paper. This was the case for Politiken some time after the critical editorial on Churchill, where correspondent Andreas Vinding in Paris wrote that Parisians were depressed at the sight of the large numbers of Germans in Paris. The reaction from the editors was that the money paying the fine was well spent.

In some cases in the first year of occupation the same paper had journalists, who were critical voices against German policy and Nazism and at the same journalists, who expressed admiration for the German war and was clearly collaborative. Berlingske Tidende employed the well-known journalist and writer Nicolai Blædel, who was forced out of the job after German demands; and at the same time the Berlin correspondent of the paper, whom the Chief Editor eventually transferred to a less prominent position because of his rather open support for the German side. Several papers employed journalists, who had expressed fundamental support for a German new order in Europe in the summer and fall of 1940, but if the journalists did not adapt to the general national and democratic "revival" in 1940/41, they were fired or they themselves changed employment to, for instance, the Danish Nazi newspapers. The more general debate and criticism on the parliamentary system and the call for non- 
political experts in Government, which especially Børsen, Jyllandsposten and Nationaltidende supported in the fall of 1940, was stopped in the beginning of 1941. From 1941 the majority of Danish papers had quite uniform positions on national and democratic issues, and traditional political divisions of the Danish press were to a large degree obliterated.

Generally, the constant repetition of the King's and the Government's call for calm and order was halted after August 29, 1943. Seen from the German side, that was the cost of a direct censorship. When there was no Danish Government in office, although still a Danish administration, gradually a more draconian German regime was introduced, with stricter rules for publications, but the Germans did not get the voluntary support for acceptance of the occupation order and their authority. The counter-media, foreign radio and clandestine papers were therefore placed in a position of greater esteem and gained more readers and listeners.

\section{Journalists and the clandestine press}

There are autobiographies or written reminiscences from a fairly large number of journalists active during the occupation. The majority of these publications are resistencialist, but a significant number of the journalists were actually active in the clandestine press as well as continuing in their jobs in the traditional controlled papers. News and studies were received at editors' desk, which was impossible to print without sanction from the Press Tribunal or without the refusal of the censorship authority. It was an obvious reaction according to professional standards and impulses to send news, that could not be printed legally, to people they knew could use the stories, and the journalists often had a large local network, and knew which people were engaged in publication of clandestine papers. Journalists were typically recruited in this way into writing for and editing clandestine papers. Therefore the stricter the rules for publication in the official press, the more news and stories were given to the clandestine press, the more professional journalists wrote in the papers and the larger was the attention, which the clandestine press received. Compared with Norway, where the majority of journalists went into exile or left the profession, this double employment of journalists at a controlled paper during the day and at a clandestine paper during evenings, was a typical reaction against open German censorship in the more lenient occupation regime in Denmark.

A number of Copenhagen journalists professionalized the distribution of news, which could not be openly printed, and created a clandestine news agency, called Information, which after liberation, was transformed into a daily newspaper. Another group of journalists formed a news agency in Sweden for the dissemination of news on occupied Denmark to the allied and neutral press, Dansk Pressetjeneste (DPT). The result was, that the comparatively modest resistance activities in Denmark compared with other European countries, received substantial attention in Allied newspapers. In most other occupied European countries such work was carried out in press offices 
connected to their Governments-in-exile in London. In the Danish case there was no such Government-in-exile, therefore the dissemination of news on Danish resistance to Allied newspapers was significant for Denmark's reputation with the Allies. The conclusion is that the vast majority of Danish journalists stayed in their jobs in the official press, and were following rules and verdicts from Danish and German authorities, but the most radical element of the journalistic community engaged in clandestine activity at the same time, and a few of them went to Sweden or England and engaged in work directly for resistance interests or Allied propaganda.

The illegal press was very diverse, and reflected in the first couple of years the values and the composition of the resistance movement. The largest and earliest paper was the communist clandestine paper Land og folk (Country and People). Second in circulation was the left wing Frit Danmark and following this a number of conservative or right wing papers, including papers connected to the Danish Unity Party, which was significant in the early non-communist resistance. Social democrats, Liberals and Social Liberals, and papers and editors connected to these parties engaged at this stage, and to a large degree also later; not in the clandestine press or in resistance as such. The main goal of the early clandestine papers was to put pressure on the official adaptation policy and turn public opinion against the occupation regime and collaborators. After August 1943 the democratic and national frames were more uniform and the debates within the clandestine press broader and with more stress on future political development at both national and international level. Discussion for and against the Soviet Union and Communism was significant, although somewhat suppressed in order not to be connected with the heavily anti-Soviet German propaganda. In Denmark radio receivers were never confiscated by the occupation authorities but listening to the $\mathrm{BBC}$ was to some degree suppressed through German jamming. Listening to the BBC was not illegal in Denmark, which was the case in nearly all other occupied countries, therefore the need for news in the Danish illegal press was limited compared with for instance Norway, where favourable Allied war news in illegal papers kept up a spirit of endurance and opposition to the occupation authorities.

\section{Readers' reactions}

During the first months after April 9, 1940 nearly all papers lost readers, generally 10 $-15 \%$. Of the papers connected to the government parties in the 1930s, Social Democrats and Social Liberals lost most, probably as a hidden protest against policies of the parties behind the Government seen as responsible for April 9. Economic insecurity was clearly responsible for a general fall in circulation. Prices soared, unemployment rose and fear of economic problems ahead was predominant. Discontinuation of subscribing to a paper was one of the obvious means of reducing expenses. A general lack of trust in news and opinions was another reason.

In the first couple of months after the April 9 war news from Norway and France had a high priority for the readers and listeners, and as news on the war mostly came 
from The German Press Agency and the daily bulletin from the German Military Command (Wehrmachtsberichte) the war news was met with considerable distrust. Already on April 13, 1940 a diarist wrote: "A really bad thing is that the press and the radio now are regimented. We only hear and read about German victories and statements from other countries which are in favour of the Germans. When I turned off the radio yesterday I said to Ida: "Were I not already in favor of the English, I would have been after such statements, but I cannot help listening to it". ${ }^{6}$ The majority of Danes suspected that controlled news was biased and especially German war news, even though the Germans at this early stage of the war did not have any unfavourable war news to hide. The German war news was initially not more inaccurate than the English news, although the German news was cloaked in an ideological language to which many Danes reacted with contempt.

Radio news in Danish from the BBC began on the evening of April 9 and very quickly received a very high audience. At this stage the news from England was not trusted completely, but it was trusted more than news from German sources. An obvious sign of distrust in all kind of media and news was the amount of rumors, personal communication and closed meetings with exchange of news and opinions. The personal diaries have scores of examples that a personal observation, even though it was only on second or third hand, always was seen as superior to and more trustworthy than any media report and news, including the $\mathrm{BBC}$ and clandestine papers. This was partly due to existence of control systems and partly due to the war and occupation experience as such.

Therefore the majority of Danes during the Occupation used a negotiated reading of war news from the beginning of the Occupation, and especially if they saw that news or articles came from German sources, but also war news from the counter-media was met with a negotiated reading. The attitude of the readers of the press to articles, editorials and comments in the press until August 29, 1943 depended on the theme or subject, and for the elite opinion also the specification of source, which at least the best educated part of the public noticed. Anything not connected with the Occupation, the war or the Germans was generally met with the same reactions as before the Occupation, and in most cases did not experience control or sanctions.

The issues, which could not be covered or discussed in the press, were taken up especially by $\mathrm{BBC}$ broadcasts in Danish and later, by the clandestine press, also a much more critical attitude to the Danish Government was predominant in the counter-media, although both the BBC and the clandestine press was until the summer of 1943 very cautious not to advocate a retreat or dismissal of the Government, because they did not reckon that the majority of Danes would agree in this. Instead they constantly attacked the Government for being too soft on the German demands, and from a very early date a number of political scapegoats were introduced to draw a line between an acceptable Danish policy and outright collaboration, seen as a patriotic policy or an unpatriotic policy. Foreign Minister (and later Prime Minister) Scavenius and Minister of Trans-

6 Edle Beyer, personal diary, April 13, 1940. 
port Gunnar Helweg-Larsen were placed beyond this line and suffered heavy and frequent attacks, although they were not put in the same category as Danish Nazis, or Danish volunteers for the Eastern Front etc. Generally these denouncements were accepted by the majority of the population.

The reading of articles and editorials connected with support for Government policy towards the Germans slowly changed into a more negotiated reading, and these articles were seen by readers as something the papers were supposed or even forced to write. The majority of readers who still bought the paper did not turn against it in non-occupied related subject-matters and most of the readers also, in general, supported their usual political party, and voted for it in the March 1943 general election. Introduction of so called "Norwegian conditions" in Denmark was a concept which many Danes could follow with a sense of admiration seen in the Norwegian context, but until the summer of 1943, it was frightening for the vast majority, if the prospect was introduction of such conditions in Denmark, and to a sizable part of the population this was also the case considerably later.

At the same time, a number of readers of the press also eagerly read a clandestine paper and its attacks on Scavenius, the Germans and Danish Nazis, although not everything in it was accepted or believed. In several respects clandestine papers were also met with a negotiated reading. A part of the population from early 1943 turned against Government policies and adaptation in general, despite what they read in their daily paper. This did not lead to an outright rejection of the wish for the continuation of a Danish government. Many wanted the comfort of the April 9 agreement and a Danish government, but at the same time admired anti-German acts.

The influence of the BBC and the clandestine press clearly had its limits. When in the fall of 1942 John Christmas Moeller, the leading Danish spokesman in London from the spring of 1942 and former leader of the Conservative Party, in a BBC broadcast, spoke out in favor of industrial and railway sabotage, contemporary sources are in agreement that the message was met with rejection by the majority of the population. Commentaries and attacks on him in the Danish press were not German-inspired, but written with a personal conviction that weakening the position of the Danish Government in its relationship with the Germans was a harmful, although not an unpatriotic, policy.

Gradually during 1944 with more open German terror, with general protest strikes and with restrictions on the daily life of ordinary Danes the vast majority of the population supported the messages in the clandestine papers and the BBC, and the governing body of resistance movements, the Resistance council (Frihedsrådet), was seen not as a political council, but as a national council. German propaganda in the press or in Danish broadcasts was considered irrelevant or was interpreted oppositional. A German message would under all circumstances be seen as wrong, misleading and unpatriotic. The newspapers survived on the non-occupation related topics and were getting ready for a new start after the anticipated liberation of the country. Surprisingly the circulation of the papers did not fall significantly during this period. 
Institutions and large companies often have a capacity for self-preservation and adaptation much like Governments and political parties. The press seen as individual institutions share this tendency. Survival of the paper, protection of the achieved circulation and local standing are first priorities, more general political and national values only second. The press experienced during the occupation the same changes in values and attitudes as the population and other institutions, so the vast majority of papers developed a stronger national and democratic frame than before the occupation. They readily adapted to the indirect control systems as long as it was seen as a part of the general adaptation policy of the Government, and were not ahead of the population in the development of stronger reactions against the cooperative policy. Arguments that adaptation and collaboration were in the interests of the German occupation authorities were generally not clarified or accepted. On the other hand the press clearly resisted attempts from the Germans through the control system or censorship to create understanding for their war, for Nazism or for the German new order.

The existence of a control system and censorship had a significant early impact on the readers creating distrust in news and articles, especially if they were seen as German-inspired or from a German source. From 1943 or 1944 a more critical attitude to adaptation and collaboration developed, but generally the public were ahead of the press, although the newspapers never were able to take positions or voice opinions directly on German occupation rule. The existence of counter media, especially BBC broadcasting, played a significant role in this development, although BBC broadcasting and clandestine papers were also met with negotiated reading and listening, but at the same time with an emotional engagement, which the daily paper could not produce.

The conclusion is that democratic values were fairly well-established in the Danish population during the war, and public opinion developed to a significant degree during the occupation according to democratic standards. It was influenced by war, by the political development and by direct public communication. The control systems of the press or the German occupation authorities were generally not able to influence the public on broader democratic or national questions.

\section{References}

Beretning til Folketinget afgivet af den af Tinget under 8. Januar 1948 nedsatte Kommission i henhold til Grundlovens § 45. 1945, 1950. København: J.H. Schultz

Bindsløv Frederiksen, L. 1960. Pressen under besættelsen. Hovedtræk af den danske dagspresses vilkår og virke i perioden 1940-45. Aarhus: Aarhus Universitetsforlag.

Bennett, Jeremy. 1966. British Broadcasting and the Danish Resistance Movement 1940-45. A Study of Wartime Broadcast of the BBC Danish Service, Cambridge: Cambridge University Press.

Boisen Schmidt, J. 1965. F.E. Jensen og Danmarks Radio under besættelsen. København: Fremad. Bruhn Jensen, Klaus, ed. 2001. Dansk Mediehistorie, bd.2, 1880-1960. København: Samleren. 
Christiansen, Ernst, et al., ed. 1950. Statsradiofonien 1925-1950. København: Gyldendal.

Gunbak, Lone Gad, and Kate Winther Christiansen. 1997. "Udenrigsministeriets Pressebureaus administration af dagbladscensuren fra 9. april 1940 til 29. august 1943". Unpublished Master thesis, Københavns Universitet.

Hvidtfeldt, Arild. 1996. I fred og krig. Erindringer indtil 1945. København: Gyldendal.

Kreth, Rasmus. 1998. Pilestræde under pres. De Berlingske Blade 1933-45. København: Berlingske Tidende.

Lauridsen, John T. 2004. “Undergrundspressen i Danmark 1940-45”, in Fund og Forskning, 261-385. København: Det Kongelige Bibliotek og MTF.

Liebes, Tamar, and Rivka Riback. 1994: "In defense of Negotiated Readings. How Moderates on Each Side of the Conflict Interpret Intifada News". In Journal of Communication, 44:2, 108-124.

Longerich, Peter. 1987. Propagandisten im Krieg. Die Presseabteilung des Auswärtigen Amtes unter Ribbentrop. München: R. Oldenbourg Verlag.

Roslyng-Jensen, Palle. 2007. Danskerne og besættelsen. Holdninger og meninger 1939-45. København: Gads Forlag.

Rousso, Henry. 1987. Le Syndrome de Vichy de 1944 à nos Jours. Paris: Seuil.

Stenton, Michael. 2000. Radio London and Resistance in Occupied Europe. British Political Warfare 1939-1943. Oxford: Oxford University Press.

Thomsen, Niels. 1972. Dagbladskonkurrencen 1870-1970. Politik, journalistik og økonomi I dansk dsagspresses strukturudvikling, 1-2. København: G.E.C. Gads Forlag.

Thomsen, Niels, and Jette Søllinge. 1991. De danske aviser, bd. III, Odense: Odense Universitetsforlag. 


\title{
Chapter Seven: \\ The Press in Eastern Europe during the Cold War
}

\author{
Peter Schiwy
}

\section{Not only the press - all media}

Even though the title of this chapter expressly mentions the word 'press', it would be inappropriate to focus exclusively on the print media in seeking to identify the clear differences between the ways in which East and West handled the dissemination of information. Anyone who studies the East-West conflict between 1945 and 1989 will quickly come to recognise that it was the cross-border exchange of information that had a decisive influence on the eventual outcome.

It would perhaps be going too far to link the technical advances made in radio and TV broadcasting during these decades with developments in media politics within the communist-ruled states of Eastern Europe, but it is worth mentioning the following factors: firstly, the introduction of VHF radio - less susceptible to interference and, though limited in geographical range, very influential within the German border areas; secondly, the improvements made in short wave reporting; thirdly, the increasingly effective use of jamming transmitters; fourthly and most importantly, the growth and increased sophistication of programming. Even now, the impact made by the transistor radio on political developments at the time has not yet been fully appreciated by students of the era. The Internet is also a 'child' of the Cold War, or rather a product of the American Defense Department, and we can take heart from the fact that this is now creating problems for party-controlled governments who merely try to pose as being democratic. You could describe the Internet as a pacesetter-if not for democracy itself, then certainly for freedom of the media.

\section{The media theory of the socialistic regime}

"A newspaper is not just a collective propagandist and agitator but also a collective organiser." This maxim was first put forward almost 105 years ago to the day. It was uttered by a certain Mr Ulyanov who later changed his name to Vladimir Ilyich Lenin. $\mathrm{He}$ is the true father of the communist theory of the media, even though he deferred to Marx who, because he never held the reins of power, seemingly formulated his own ideas in a more democratic and libertarian fashion.

Nowadays, we all know full well what Marx and Lenin meant: we have seen at first hand a system which interpreted information as synonymous with agitation and propaganda. And yet, these concepts, which have such negative associations for us, were ideologically prescribed under socialism as defined by Lenin, Stalin, Brezhnev and 